\title{
Treatment of malignant tumors of the skull base with multi-session
} radiosurgery Nicholas D Coppa ${ }^{1}$, Daniel MS Raper ${ }^{4}$, Ying Zhang 3 , Brian T Collins², K
William Harter $^{2}$, Gregory J Gagnon ${ }^{2}$, Sean P Collins ${ }^{2}$ and Walter C Jean*1,2

Address: ${ }^{1}$ Department of Neurosurgery, Georgetown University Hospital, Washington, DC, USA, ${ }^{2}$ Department of Radiation Oncology, Georgetown University Hospital, Washington, DC, USA, ${ }^{3}$ Biostatistics Unit, Lombardi Comprehensive Cancer Center, Georgetown University Medical Center, Washington, DC, USA and ${ }^{4}$ Faculty of Medicine, University of Sydney, Sydney, Australia

Email: Nicholas D Coppa - ndcoppa@gmail.com; Daniel MS Raper - drap7157@gmp.usyd.edu.au; Ying Zhang - yz9@georgetown.edu; Brian T Collins - collinsb@gunet.georgetown.edu; K William Harter - harterk@gunet.georgetown.edu;

Gregory J Gagnon - gagnong@gunet.georgetown.edu; Sean P Collins - mbppkia@hotmail.com; Walter C Jean* - WCJ4@gunet.georgetown.edu

* Corresponding author

Published: 2 April 2009

Journal of Hematology \& Oncology 2009, 2:16 doi:10.1186/1756-8722-2-16
Received: 18 January 2009

Accepted: 2 April 2009

This article is available from: http://www.jhoonline.org/content/2/1/16

(C) 2009 Coppa et al; licensee BioMed Central Ltd.

This is an Open Access article distributed under the terms of the Creative Commons Attribution License (http://creativecommons.org/licenses/by/2.0), which permits unrestricted use, distribution, and reproduction in any medium, provided the original work is properly cited.

\begin{abstract}
Objective: Malignant tumors that involve the skull base pose significant challenges to the clinician because of the proximity of critical neurovascular structures and limited effectiveness of surgical resection without major morbidity. The purpose of this study was to evaluate the efficacy and safety of multi-session radiosurgery in patients with malignancies of the skull base.

Methods: Clinical and radiographic data for 37 patients treated with image-guided, multi-session radiosurgery between January 2002 and December 2007 were reviewed retrospectively. Lesions were classified according to involvement with the bones of the base of the skull and proximity to the cranial nerves.

Results: Our cohort consisted of 37 patients. Six patients with follow-up periods less than four weeks were eliminated from statistical consideration, thus leaving the data from $3 \mathrm{I}$ patients to be analyzed. The median follow-up was 37 weeks. Ten patients (32\%) were alive at the end of the follow-up period. At last follow-up, or the time of death from systemic disease, tumor regression or stable local disease was observed in 23 lesions, representing an overall tumor control rate of $74 \%$. For the remainder of lesions, the median time to progression was 24 weeks. The median progression-free survival was 230 weeks. The median overall survival was 39 weeks. In the absence of tumor progression, there were no cranial nerve, brainstem or vascular complications referable specifically to CyberKnife ${ }^{\circledR}$ radiosurgery.

Conclusion: Our experience suggests that multi-session radiosurgery for the treatment of malignant skull base tumors is comparable to other radiosurgical techniques in progression-free survival, local tumor control, and adverse effects.
\end{abstract}




\section{Introduction}

A variety of malignant tumors can involve the skull base. These tumors may originate from various tissues of the skull base, or invade into the region as extensions of head and neck cancers [1,2]. The skull base is also a common site of metastasis from distant tumors $[3,4]$. Patients with skull base malignancies suffer greatly [5]. Common clinical presentations include pain and cranial nerve deficits, such as visual disturbances, facial paresis and swallowing difficulties [3]. Treatment of these tumors presents formidable challenges to the clinician. In addition to neurological factors, such as the close proximity of critical neurovascular structures, oncological factors play a key role. Metastatic skull base tumors are often late complications of systemic cancers, and the advanced systemic tumor burden, poor overall clinical condition and the morbidities from prior interventions, all make treatment difficult $[6,7]$.

Historically, malignant skull base tumors were deemed inoperable and the overall prognosis was poor, especially for those presenting with cranial nerve deficits [8,9]. Surgical resection was frequently incomplete and limited by high mortality, risk of severe neurological morbidity and frequent recurrences [10-13]. Important technical advancements such as improved understanding of the microanatomy of the area, higher-resolution diagnostic imaging, safer operative strategies, and multidisciplinary collaboration have evolved over the past three decades, making surgical treatment safer $[14,15]$. Surgical resection or debulking is currently considered a critical component of their management $[16,17]$. But, even though some authors regard surgery as the "gold standard" treatment, the limitations of brainstem and cranial nerve morbidities continue to make curative resections a rarity [18-20].

There is an important role for radiation therapy in the management of skull base malignancies, both as primary treatment as well as adjuvant treatment, after surgical resection [21-26]. However, as with surgery for these tumors, the limitations of this therapy are readily apparent. External beam radiation therapy alone results in poor local control and overall survival due to factors such as large tumor volume, limitations of radiation dose, and the intrinsic "radio-resistance" of certain tumors [27,28]. Single-session radiosurgery has been employed in the treatment of chordomas and malignant tumors at the cranial base [3,29-34]. However, given the close proximity of these lesions to critical neurovascular structures, methods to minimize radiation-induced toxicities should be considered. [35-45]. More recently, "hypofractionated" or staged radiosurgery has provided an attractive alternative. This therapy has been successfully utilized in the treatment of tumors in which preservation of surrounding structures is particularly vital, such as those near the optic nerve and optic chiasm, as well as for various lesions at the skull base [46-49]. The hiatus between treatment sessions theoretically provides time for normal tissue repair, and the resultant lower radiation risk to the normal structures permits more effective treatment of the target lesion [50]. This therapy may be particularly useful for patients with skull base malignancies, for whom the essential goal of treatment is for palliation rather than cure [31].

The CyberKnife ${ }^{\circledast}$ is an image-guided, frameless radiosurgical system that uses inverse planning for the delivery of radiation to a defined target volume [51]. Non-isocentric radiation delivery permits simultaneous treatment of multiple lesions, and the frameless configuration allows for staged treatment. It has been successfully utilized to treat various skull base lesions including chordomas and plasmacytomas among many others $[47,49]$. We utilized the CyberKnife ${ }^{\circledR}$ to treat skull base malignancies, believing that it is useful for managing these relatively rare but highly challenging tumors. In this retrospective study, we evaluated the efficacy and safety of staged stereotactic radiosurgery for treatment of malignant skull base tumors, either as a primary treatment modality or as an adjunct to surgery and conventional external beam radiotherapy.

\section{Patients and methods Patient Population}

We performed a retrospective review of 464 patients with intracranial tumors who were treated with CyberKnife ${ }^{\circledast}$ stereotactic radiosurgery (CKS) at Georgetown University Hospital between January 2002 and December 2007. One hundred forty-five patients were classified as having tumors of the skull base, of which 108 were benign. Thirty-seven patients had 37 lesions that were classified as malignant skull base tumors. Six patients who had followup periods less than or equal to four weeks were eliminated from statistical consideration, thus leaving 31 patients for analysis.

For the purposes of this study, skull base lesions were defined as those that involved the osseous structures of the base of the skull, in close proximity to the critical neurovascular structures of the region. All the tumors included in this study either completely encircled, partially circumscribed, or directly contacted the brainstem, optic chiasm, or cranial nerves with meaningful remaining function. Primary brain tumors were excluded, unless they had the potential to metastasize and were thus considered malignant. An example of such a tumor is a hemagiopericytoma. Malignant orbital, sinus and head-andneck tumors were included in this study only if there was intracranial extension.

This malignant skull base tumor group consisted of 21 men and 10 women, with a median age of 57 (range: 11 - 81) (Table 1). The histopathology of all tumors was 
Table I: Patient characteristics

\begin{tabular}{lc}
\hline & Study Group \\
\hline Number of patients & 31 \\
Number of lesions & 31 \\
Gender & \\
Male & 21 \\
Female & 10 \\
Age & \\
Min & 11 \\
Max & 81 \\
Median & 53 \\
Mean & 57 \\
\hline
\end{tabular}

either known from prior microsurgical resection, biopsy, or was presumed based on the intracranial extension of known head and neck cancers.

\section{Radiosurgical Treatment Planning and Delivery}

A multidisciplinary meeting of specialists that included neurosurgeons, otolaryngologists, radiation oncologists, medical oncologists, and neuroradiologists evaluated all patients. A collective decision to treat with radiosurgery was made for each individual patient. Radiosurgery was only offered to patients for whom conventional microsurgical resection was contraindicated because of high neurological risk, overwhelming medical comorbidities, poor prognosis with limited survival, or recurrent disease in the presence of prior microsurgical resection, chemotherapy and radiation therapy.

The CyberKnife ${ }^{\circledast}$ radiosurgical system was used to administer cranial radiosurgery in every case. The technical aspects of CKS for cranial tumors have been described in detail $[46,50]$. Briefly, the patient's head was immobilized by a malleable thermoplastic mask during the acquisition of a thin-sliced $(1.25 \mathrm{~mm})$ high-resolution computed tomography scan, which was used for treatment planning. The use of a contrast-enhanced MRI fused to the treatment planning CT scan was at the discretion of the treating physicians. This decision was influenced by various factors, such as previous radiation to the area, performance status, treatment intent and extent of contact and compression of critical neurological structures. The target volumes and critical structures were then delineated by the treating neurosurgeon. An inverse planning method with non-isocenteric technique was used for all cases, with specific dose constraints on critical structures such as the optic chiasm and brainstem. The planning software calculated the optimal solution for treatment, and the dose-volume histogram of each plan was evaluated until an acceptable plan was found. The treating neurosurgeon and radiation oncologist, who have a shared responsibility for all aspects of the treatment planning and procedure, determined the minimal tumor margin dose of the target vol- ume, the treatment isodose and the number of treatment sessions into which the total dose was to be divided. This decision was influenced by various factors, such as previous radiation to the area, tumor volume, and extent of contact and compression of critical neurological structures. In most cases, the treatment dose was prescribed to the isodose surface that encompassed the margin of the tumor.

The delivery of radiosurgery by the CyberKnife ${ }^{\circledast}$ was guided by real-time imaging. Using computed tomography planning, target volume locations were related to radiographic landmarks of the cranium. With the assumption that the target position is fixed within the cranium, cranial tracking allowed for anatomy based tracking relatively independent of patient's daily setup. Position verification was validated several times per minute during treatment using paired, orthogonal, $\mathrm{x}$-ray images.

\section{Caclulation of Radiosurgical Treatment Planning Parameters}

The homogeneity index and new conformity index were calculated for each treatment plan. The homogeneity index (HI) describes the uniformity of dose within a treated target volume, and is directly calculated from the prescription isodose line chosen to cover the margin of the tumor. It is calculated by the following equation:

$$
\begin{aligned}
\mathrm{HI}= & (\text { max imum dose }) \\
& (\text { prescription dose })
\end{aligned}
$$

The new conformity index (NCI) as formulated by Paddick, and modified by Nakamura, describes the degree to which the prescribed isodose volume conforms to the shape and size of the target volume $[52,53]$. It also takes into account avoidance of surrounding normal tissue. It is calculated by the following equation:

$$
\mathrm{NCI}=\quad\left[\begin{array}{c}
\text { (treatment volume }) \quad(\text { prescription isodose volume })] \\
(\text { volume of the target covered by the prescription isodose volume })^{2}
\end{array}\right.
$$

\section{Clinical Assessment and Follow- Up}

Post-radiosurgical follow-up was typically performed in a multidisciplinary clinic of the treating neurosurgeon and radiation oncologist beginning one month after the conclusion of radiosurgery. Patients were subsequently followed in three-month intervals. During each follow-up visit, a clinical evaluation and physical examination were performed as well as a review of pertinent radiographic imaging. If a patient experienced deterioration in their clinical condition at any point during the follow-up period, an immediate evaluation was performed. The progress of all patients was discussed periodically at a multidisciplinary tumor conference of various specialists, ensuring precise interpretation of the available data. We 
analyzed tumor response, clinical outcome, treatmentrelated complications and survival during the follow-up period.

\section{Results}

\section{Patient and tumor characteristics}

The characteristics of the study group including the distribution of gender, age, tumor histology and location are detailed below and summarized in Tables 1 and 2. The most frequent tumors in this series were squamous cell

Table 2: Skull base tumor characteristics

\begin{tabular}{|c|c|}
\hline & Study Group \\
\hline \multicolumn{2}{|l|}{ Volume (cc) } \\
\hline Min & 3.2 \\
\hline $\operatorname{Max}$ & 206.5 \\
\hline Mean & 41.6 \\
\hline Median & 18.3 \\
\hline \multicolumn{2}{|l|}{ Histology } \\
\hline Adenoid cystic carcinoma & 5 \\
\hline Breast cancer & I \\
\hline Chondrosarcoma & 1 \\
\hline Ewing sarcoma & 2 \\
\hline Hemangiopericytoma & 1 \\
\hline Hepatocellular carcinoma & I \\
\hline Leiomyosarcoma & 1 \\
\hline Melanoma & 3 \\
\hline Papillary thyroid carcinoma & 1 \\
\hline Parotid adenocarcinoma & 2 \\
\hline Renal cell carcinoma & 3 \\
\hline Rhabdomyosarcoma & 2 \\
\hline Spindle cell carcinoma & 1 \\
\hline Squamous cell carcinoma & 6 \\
\hline Transitional cell carcinoma & 1 \\
\hline \multicolumn{2}{|l|}{ Location } \\
\hline Cavernous sinus & 8 \\
\hline Cribriform plate & 1 \\
\hline $\mathrm{CP}$ angle/IAC & 2 \\
\hline Ethmoid & 1 \\
\hline Foramen magnum & I \\
\hline Foramen ovale & I \\
\hline Infratemporal fossa & 3 \\
\hline Jugular foramen & I \\
\hline Middle fossa & 2 \\
\hline Parasellar & 1 \\
\hline Orbit & 7 \\
\hline Petroclival & 3 \\
\hline \multicolumn{2}{|l|}{ Goal of CyberKnife treatment } \\
\hline Primary treatment for local disease (\%) & $18(58)$ \\
\hline Secondary treatment $(\%)$ & $13(42)$ \\
\hline \multicolumn{2}{|l|}{ Previous treatment } \\
\hline Previous craniofacial surgery & 6 \\
\hline Previous external beam radiation & 4 \\
\hline Previous stereotactic radiosurgery & I \\
\hline Previous biopsy only (\%) & 4 \\
\hline
\end{tabular}

carcinoma (6 lesions), adenoid cystic carcinoma (5 lesions), rhabdomyosarcoma (2 lesions) and metastases of melanoma and renal cell carcinomas (3 lesions each). The median tumor volume was 18.3 cc (range: 3.2 - 206.5 cc).

Tumors varied in their skull base location, as illustrated in Table 2. A number of lesions, however, spanned multiple anatomical locations. CKS was the primary treatment to the malignant skull base tumor in 18 patients (58\%). Of the 13 patients with previous treatment to the tumor involved in this study, 6 (46\%) had previous craniofacial surgery, 4 (30\%) had previous external beam radiation, and $1(7 \%)$ had previous stereotactic radiotherapy. Four patients (13\% of the entire series) had undergone biopsy only.

\section{Radiosurgical treatment}

The specific dose and fractionation scheme for the tumors in this series was influenced by various factors, including previous radiation to the area, tumor volume, and extent of contact and compression of critical neurological structures. Details of the radiosurgical treatments are found in Table 3. A median treatment dose of 2500 cGy was deliv-

Table 3: Radiosurgery treatment plan

\begin{tabular}{|c|c|}
\hline & Study Group \\
\hline \multicolumn{2}{|l|}{ Dose (cGy) } \\
\hline Min & 1260 \\
\hline $\operatorname{Max}$ & 3500 \\
\hline Mean & 2449 \\
\hline Median & 2500 \\
\hline \multicolumn{2}{|c|}{ Treatment Stages } \\
\hline Min & 2 \\
\hline Max & 7 \\
\hline Mean & 4.45 \\
\hline Median & 5 \\
\hline \multicolumn{2}{|c|}{ Homogeneity Index } \\
\hline Min & 1.14 \\
\hline Max & 2.44 \\
\hline Mean & 1.34 \\
\hline Median & 1.32 \\
\hline \multicolumn{2}{|c|}{ New Conformality Index } \\
\hline Min & 1.29 \\
\hline $\operatorname{Max}$ & 2.59 \\
\hline Mean & 1.70 \\
\hline Median & 1.60 \\
\hline \multicolumn{2}{|c|}{ Isodose Line (\%) } \\
\hline Min & 68 \\
\hline $\operatorname{Max}$ & 88 \\
\hline Mean & 77 \\
\hline Median & 75 \\
\hline
\end{tabular}


ered to the margins of the tumors in this study (range: 1260 - $3500 \mathrm{cGy}$ ). Radiosurgery was delivered during a median number of 5 sessions (range: $2-7$ ) on a median isodose line of $75 \%$ (range: $68-88 \%$ ) as defined at the margin of the treated tumor. The median homogeneity index (HI), a measure of dose homogeneity to the tumor, was 1.32 (range: $1.11-2.44$ ). For the lesions where it was available (28 lesions), the median new conformity index (NCI) was 1.60 (range: $1.29-2.59$ ).

\section{Tumor Control}

The median follow-up was 37 weeks (range: $6-238$ weeks) (Tables 4 \&5). At last follow-up, or at the time of death from systemic disease, 5 tumors $(16 \%)$ had regressed, and 18 (58\%) exhibited stable local disease (Figure 1 and Table 4). Eight lesions (26\%) progressed locally despite treatment (Figure 2). The overall tumor control rate in these 31 patients was $74 \%$.

For those patients with local progression, the median time to progression was 24 weeks (range: 5 - 230 weeks). One patient with a renal cell carcinoma metastasis to the right jugular foramen/CPA who experienced local progression at 31 weeks underwent a second course of CKS, which halted further progression and resulted in subsequent local control at a follow-up of 72 weeks.

\section{Survival}

Ten patients (32\%) were alive at the end of the follow-up period, having survived a median of 81 weeks (range: 18 - 238 weeks). For the 21 patients (68\%) who died, the

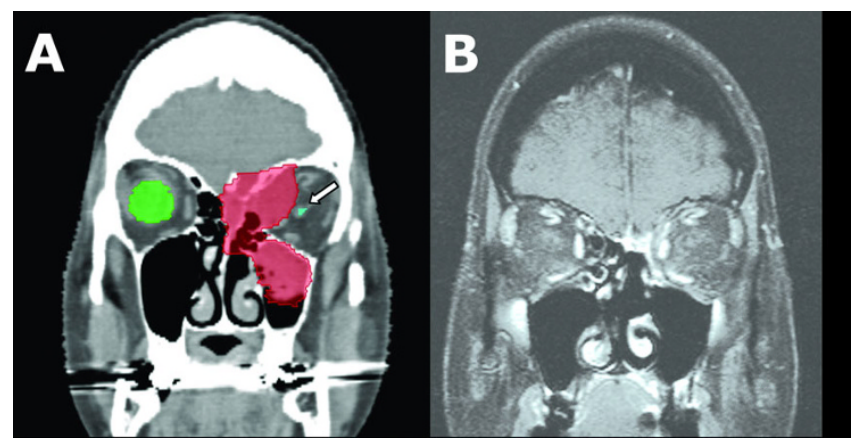

Figure I

57-year-old woman with squamous cell carcinoma of the left ethmoid sinus, orbit and anterior skull base.

Prior to consideration of radiosurgery, the original treatment plan was craniofacial resection with left orbital exenteration. She was treated with 3000 cGy in 5 stages. (A) Coronal CT with contrast prior to radiosurgery with treatment-planning contour. The tumor is shaded in red. Note proximity of left optic nerve. White arrow: optic nerve. (B) Coronal MRI with contrast 13 months after radiosurgery showing dramatic response. Currently, the patient continues to have normal binocular vision nearly 4 years after treatment.

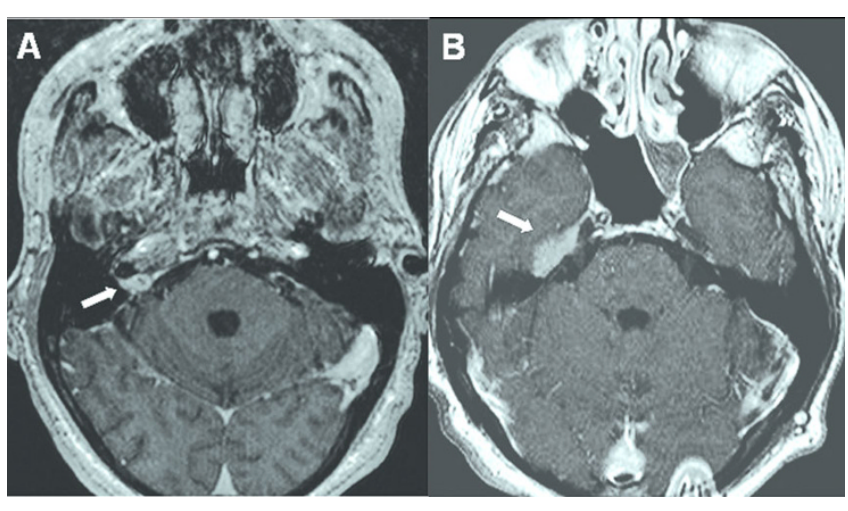

Figure 2

50-year-old man with biopsy-proven renal cell carcinoma to the right internal acoustic meatus (IAM). He was treated with 2500 cGy in 5 stages. (A) Axial MRI with contrast prior to radiosurgery showing the tumor at the IAM. White arrow: tumor. (B) Axial MRI with contrast 5 months after radiosurgery showing extension of disease cephalad. This area was treated with an additional 2400 cGy in 3 stages. White arrow: tumor extension.

median time to death was 25 weeks (range: 6 - 142 weeks) (Tables 4 \&5). Among those patients who died, 5 (25\%) had local progression. However, no patients died specifically from radiosurgery-treated disease or treatment-related complications. The median progression-free survival of the cohort was 230 weeks (Figure 3). The median overall survival of the cohort was 39 weeks (Figure 4).

Table 4: Treatment outcomes after CyberKnife radiosurgery

\begin{tabular}{lc}
\hline & Study Group \\
\hline Follow-up (weeks) & \\
Min & 6 \\
Max & 238 \\
Mean & 54 \\
Median & 37 \\
Survival at last follow-up (\%) & $10(32)$ \\
Time to Death & \\
Min & 6 \\
Max & 142 \\
Mean & 32 \\
Median & 25 \\
Local disease outcome & \\
Disease regression (\%) & $5(16)$ \\
Stable disease (\%) & $18(58)$ \\
Disease progression (\%) & $8(26)$ \\
Death due to treated disease (\%) & $0(0)$ \\
Time to local progression (weeks) & \\
Min & 5 \\
Max & 230 \\
Mean & 47 \\
Median & 24 \\
\hline
\end{tabular}


Table 5: Treatment outcomes after CyberKnife radiosurgery

\begin{tabular}{|c|c|c|c|c|c|c|c|c|}
\hline Patient & Histology & Prior Surgery & $\begin{array}{c}\text { Prior } \\
\text { Radiation }\end{array}$ & $\begin{array}{c}\text { Local } \\
\text { Outcome }\end{array}$ & $\begin{array}{l}\text { Time to } \\
\text { Progression } \\
\text { (wks) }\end{array}$ & Status & $\begin{array}{c}\text { Time to } \\
\text { Death (wks) }\end{array}$ & $\begin{array}{l}\text { Clinical } \\
\text { Follow-up } \\
\text { (wks) }\end{array}$ \\
\hline 1 & $\begin{array}{l}\text { Adenoid Cystic } \\
\text { Carcinoma }\end{array}$ & $\mathrm{n} / \mathrm{a}$ & EBRT & Progressed & 230 & Alive & $\mathrm{n} / \mathrm{a}$ & 230 \\
\hline 2 & $\begin{array}{l}\text { Squamous Cell } \\
\text { Carcinoma }\end{array}$ & $\mathrm{n} / \mathrm{a}$ & $\mathrm{n} / \mathrm{a}$ & Regressed & $\mathrm{n} / \mathrm{a}$ & Alive & $\mathrm{n} / \mathrm{a}$ & 192 \\
\hline 3 & $\begin{array}{l}\text { Adenoid Cystic } \\
\text { Carcinoma }\end{array}$ & $\mathrm{n} / \mathrm{a}$ & $\mathrm{n} / \mathrm{a}$ & Stable & $\mathrm{n} / \mathrm{a}$ & Alive & $\mathrm{n} / \mathrm{a}$ & 161 \\
\hline 4 & $\begin{array}{l}\text { Squamouc Cell } \\
\text { Carcinoma }\end{array}$ & Resection & EBRT & Stable & $\mathrm{n} / \mathrm{a}$ & Dead & 142 & 142 \\
\hline 5 & $\begin{array}{l}\text { Renal Cell } \\
\text { Carcinoma }\end{array}$ & $\mathrm{n} / \mathrm{a}$ & $\mathrm{n} / \mathrm{a}$ & Stable & $\mathrm{n} / \mathrm{a}$ & Alive & $\mathrm{n} / \mathrm{a}$ & 86 \\
\hline 6 & $\begin{array}{l}\text { Adenoid Cystic } \\
\text { Carcinoma }\end{array}$ & $\mathrm{n} / \mathrm{a}$ & $\mathrm{n} / \mathrm{a}$ & Stable & $n / a$ & Alive & $n / a$ & 82 \\
\hline 7 & $\begin{array}{l}\text { Renal Cell } \\
\text { Carcinoma }\end{array}$ & $\mathrm{n} / \mathrm{a}$ & $\mathrm{n} / \mathrm{a}$ & Progressed & 31 & Alive & $\mathrm{n} / \mathrm{a}$ & 79 \\
\hline 8 & Melanoma & $\mathrm{n} / \mathrm{a}$ & $\mathrm{n} / \mathrm{a}$ & Progressed & 40 & Dead & 77 & 77 \\
\hline 9 & $\begin{array}{c}\text { Hemangioperic } \\
\text { ytoma }\end{array}$ & Resection & $\mathrm{n} / \mathrm{a}$ & Regressed & $\mathrm{n} / \mathrm{a}$ & Alive & $n / a$ & 66 \\
\hline 10 & $\begin{array}{c}\text { Chondrosarco } \\
\text { ma }\end{array}$ & $\mathrm{n} / \mathrm{a}$ & $\mathrm{n} / \mathrm{a}$ & Stable & $\mathrm{n} / \mathrm{a}$ & Alive & $\mathrm{n} / \mathrm{a}$ & 52 \\
\hline 11 & $\begin{array}{l}\text { Squamous Cell } \\
\text { Carcinoma }\end{array}$ & Resection & $\mathrm{n} / \mathrm{a}$ & Progressed & 5 & Dead & 52 & 52 \\
\hline 12 & $\begin{array}{l}\text { Rhabdomyosarc } \\
\text { oma }\end{array}$ & $\mathrm{n} / \mathrm{a}$ & $\mathrm{n} / \mathrm{a}$ & Stable & $n / a$ & Alive & $n / a$ & 49 \\
\hline 13 & $\begin{array}{l}\text { Spindle Cell } \\
\text { Carcinoma }\end{array}$ & Resection & $\mathrm{n} / \mathrm{a}$ & Progressed & 32 & Dead & 46 & 46 \\
\hline 14 & $\begin{array}{l}\text { Transitional } \\
\text { Cell Carcinoma }\end{array}$ & Biopsy & EBRT & Stable & $\mathrm{n} / \mathrm{a}$ & Dead & 41 & 41 \\
\hline 15 & Melanoma & $\mathrm{n} / \mathrm{a}$ & $\mathrm{n} / \mathrm{a}$ & Stable & $\mathrm{n} / \mathrm{a}$ & Dead & 39 & 39 \\
\hline 16 & $\begin{array}{l}\text { Squamous Cell } \\
\text { Carcinoma }\end{array}$ & $\mathrm{n} / \mathrm{a}$ & EBRT & Regressed & $\mathrm{n} / \mathrm{a}$ & Dead & 37 & 37 \\
\hline 17 & $\begin{array}{l}\text { Rhabdomyosarc } \\
\text { oma }\end{array}$ & $\mathrm{n} / \mathrm{a}$ & EBRT & Stable & $n / a$ & Dead & 35 & 35 \\
\hline 18 & $\begin{array}{l}\text { Papillary } \\
\text { Thyroid } \\
\text { Carcinoma }\end{array}$ & $\mathrm{n} / \mathrm{a}$ & $n / a$ & Regressed & $\mathrm{n} / \mathrm{a}$ & Dead & 29 & 29 \\
\hline 19 & $\begin{array}{c}\text { Leiomyosarcom } \\
\mathrm{a}\end{array}$ & $\mathrm{n} / \mathrm{a}$ & $\mathrm{n} / \mathrm{a}$ & Stable & $\mathrm{n} / \mathrm{a}$ & Dead & 28 & 28 \\
\hline
\end{tabular}


Table 5: Treatment outcomes after CyberKnife radiosurgery (Continued)

\begin{tabular}{|c|c|c|c|c|c|c|c|c|}
\hline 20 & Melanoma & $\mathrm{n} / \mathrm{a}$ & RS & Progressed & 16 & Dead & 21 & 21 \\
\hline 21 & Ewing Sarcoma & $\mathrm{n} / \mathrm{a}$ & EBRT & Stable & $\mathrm{n} / \mathrm{a}$ & Dead & 20 & 20 \\
\hline 22 & $\begin{array}{c}\text { Adenocarcinom } \\
\text { a } \\
\text { (Parotid Gland) }\end{array}$ & $\mathrm{n} / \mathrm{a}$ & EBRT & Stable & $\mathrm{n} / \mathrm{a}$ & Dead & 18 & 18 \\
\hline 23 & $\begin{array}{l}\text { Squamous Cell } \\
\text { Carcinoma }\end{array}$ & $\mathrm{n} / \mathrm{a}$ & $\mathrm{n} / \mathrm{a}$ & Progressed & 12 & Alive & $n / a$ & 18 \\
\hline 24 & $\begin{array}{l}\text { Hepatocellular } \\
\text { Carcinoma }\end{array}$ & $\mathrm{n} / \mathrm{a}$ & $\mathrm{n} / \mathrm{a}$ & Stable & $\mathrm{n} / \mathrm{a}$ & Dead & 13 & 13 \\
\hline 25 & $\begin{array}{l}\text { Squamous Cell } \\
\text { Carcinoma }\end{array}$ & $\mathrm{n} / \mathrm{a}$ & $\mathrm{n} / \mathrm{a}$ & Progressed & 9 & Dead & 13 & 13 \\
\hline 26 & $\begin{array}{c}\text { Adenoic Cystic } \\
\text { Carcinoma }\end{array}$ & Resection & EBRT & Regressed & $\mathrm{n} / \mathrm{a}$ & Dead & 11 & II \\
\hline 27 & $\begin{array}{l}\text { Renal Cell } \\
\text { Carcinoma }\end{array}$ & $\mathrm{n} / \mathrm{a}$ & $\mathrm{n} / \mathrm{a}$ & Stable & $\mathrm{n} / \mathrm{a}$ & Dead & 10 & 10 \\
\hline 28 & Ewing Sarcoma & $\mathrm{n} / \mathrm{a}$ & EBRT & Stable & $\mathrm{n} / \mathrm{a}$ & Dead & 8 & 8 \\
\hline 29 & $\begin{array}{c}\text { Adenocarcinom } \\
\text { a } \\
\text { (Parotid Gland) }\end{array}$ & $\mathrm{n} / \mathrm{a}$ & $\mathrm{n} / \mathrm{a}$ & Stable & $\mathrm{n} / \mathrm{a}$ & Dead & 8 & 8 \\
\hline 30 & $\begin{array}{c}\text { Breast } \\
\text { Carcinoma }\end{array}$ & $\mathrm{n} / \mathrm{a}$ & $\mathrm{n} / \mathrm{a}$ & Stable & $\mathrm{n} / \mathrm{a}$ & Dead & 7 & 7 \\
\hline 31 & $\begin{array}{l}\text { Adenoid Cystic } \\
\text { Carcinoma }\end{array}$ & Resection & EBRT & Stable & $\mathrm{n} / \mathrm{a}$ & Dead & 6 & 6 \\
\hline
\end{tabular}

Tumor Control and Survival as a Function of "StandAlone" Radiosurgery versus "Adjunctive" Radiosurgery The follow-up clinical data were compared between the groups of patients for whom CKS was primary "standalone" treatment versus secondary treatment following surgery or external beam radiotherapy. Among the patients with adequate follow-up data, 18 patients were treated with CKS as a primary treatment. The median follow-up was 44 weeks (range: 7 - 238 weeks). Nine patients (50\%) were alive at the end of the follow-up period, and 5 (27\%) experienced local tumor progression, with a median time to progression of 31 weeks (range: 9 - 230 weeks).

For the 13 patients with previous treatments for their skull base lesion, the median follow-up was 35 weeks (range: 6 - 142 weeks). One patient ( $8 \%$ ) was alive at the end of the follow-up period, and 3 (23\%) experienced local tumor progression, with a median time to progression of 16 weeks (range: 5 - 32 weeks).

\section{Toxicity}

The neurological deficits before and after CKS are summarized in Table 6 . Altered vision comprised the most com- mon presenting symptom prior to radiosurgery, with 10 patients having reduced visual acuity, 13 patients having diplopia, and 1 patient having proptosis. Four patients (40\%) experienced improved visual acuity and three patients (23\%) experienced improvement from their diplopia following treatment. Otherwise, all symptoms remained stable at last follow-up. Of the 17 patients with facial weakness or facial pain on physical examination prior to CKS, 15 (88\%) remained stable at last follow-up. One patient $(6 \%)$ with facial weakness reported improvement. In one patient, facial weakness and swallowing difficulty worsened following CKS due to local disease progression involving all cranial nerves. Swallowing difficulties were found in four patients, $75 \%$ of which remained stable following treatment (Figure 5). In the absence of tumor progression, there were no cranial nerve, brainstem or vascular complications referable specifically to CyberKnife $^{\circledR}$ radiosurgery. Specifically, there were no new cranial nerve deficits observed following SRS in this series.

\section{Discussion}

Skull base malignancies pose unique challenges to the clinician because of oncological and neurological factors. 


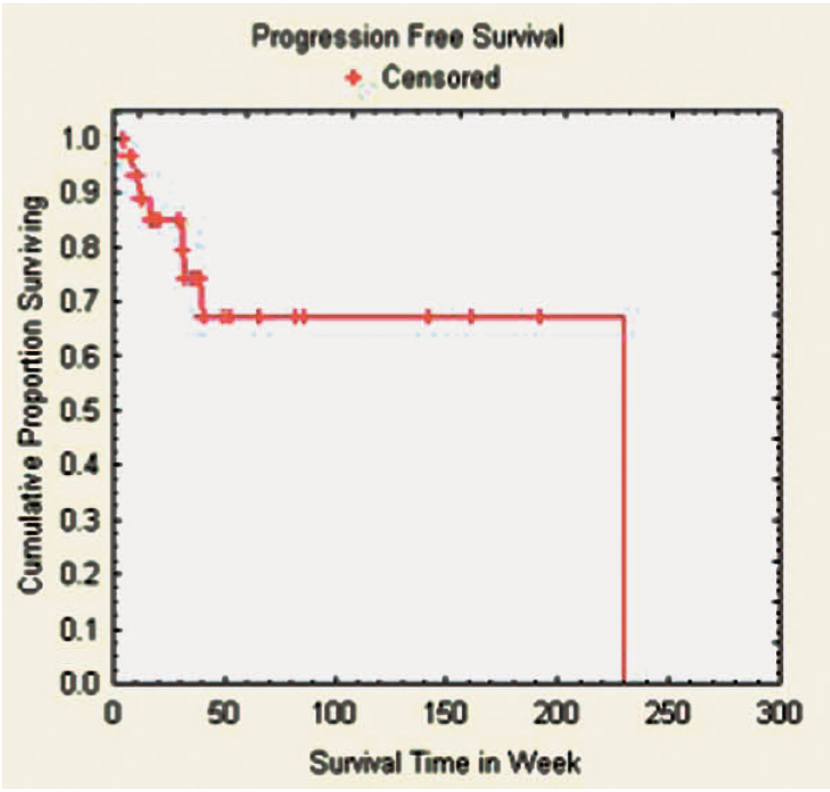

Figure 3

Progression-free survival.

Since these tumors present late in the course of the patients' disease, they are often poor candidates for aggressive therapy. And because these tumors are in close proximity or contact with the brain stem and cranial nerves, complete surgical resection is almost uniformly impossible without significant neurological injury. External beam radiation has had limited success in treating these malignancies largely due to dose-limitations $[27,28]$. Given the results of the current study, we feel that

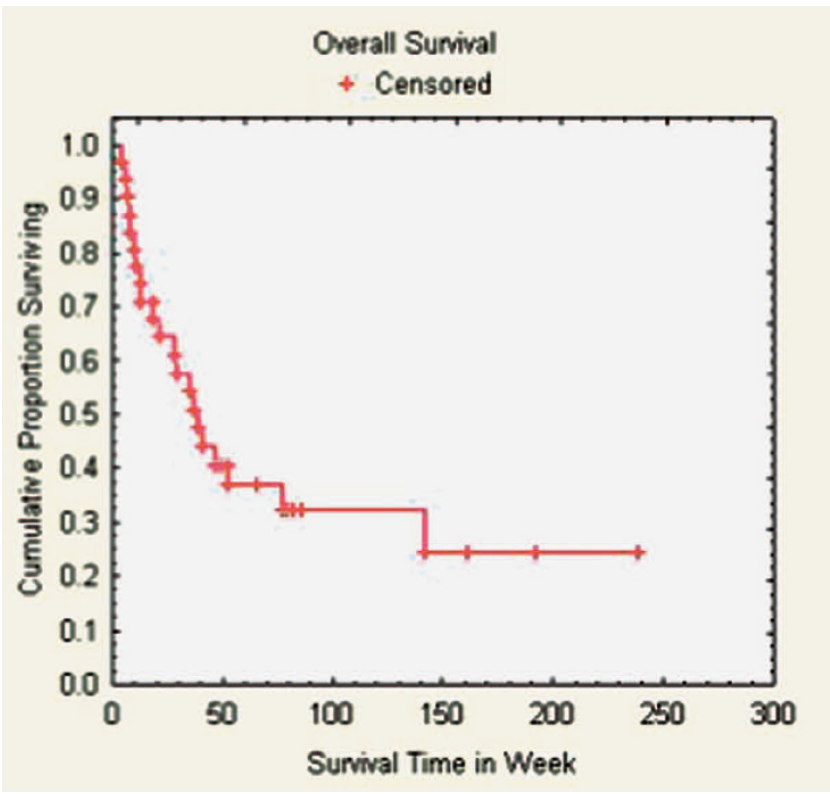

Figure 4

Overall survival. microsurgical resection of skull base malignancies may no longer be the "gold-standard" or optimal first-line treatment. Cases should be evaluated on an individual basis by a multi-disciplinary team so that the best treatment, capitalizing on the advances in skull base microsurgery and radiation oncology, can be delivered.

\section{Review of the Literature}

Radiosurgery may be uniquely suitable for treating these tumors, since it is non-invasive and can precisely target the tumor with minimal spread of radiation to surrounding normal neurological structures. Various investigators have reported their experience with stereotactic radiosurgery in the treatment of malignant skull base tumors. Cmelak et al. reported their data on 47 patients with 59 malignant skull base tumors [54]. Eleven patients with primary nasopharyngeal carcinoma were treated with Linac radiosurgery as a boost ( $7-16 \mathrm{~Gy}$, median: $12 \mathrm{~Gy})$ after a course of fractionated radiotherapy. None of the eleven had tumor progression during the follow-up period. The rest of the patients were treated for skull base metastases or local recurrences from primary head and neck cancers. Radiation doses of 7.0 Gy - 35.0 Gy (median 20.0 Gy) were delivered to these lesions, usually as a single fraction. A tumor control rate of $69 \%$ was reported for these patients during the study period (median: 36 weeks). Major toxicities occurred after 5 of 59 treatments. These included three cranial nerve palsies, one CSF leak, and one case of trismus. An important conclusion from their data was that local control did not correlate with lesion size, histology, or radiosurgical dose.

Two small studies from Japan showed similar results. Tanaka et al. reported on 19 malignant skull base tumors, which they treated with single fraction gamma knife radiosurgery [33]. The mean marginal dose utilized was 12.9 Gy. During a follow-up period of 22 months, a tumor control rate of $68 \%$ was recorded. The other study by Iwai and Yamanaka of 18 similar patients showed a tumor control rate of $67 \%$ during a median follow up of 10 months [31]. A local control rate as high as $95 \%$ at 2 years has been reported in one radiosurgery study, but the patient population in that series included 66\% with skull base chordomas, chondrosarcomas and adenoid cystic carcinomas, which differ significantly from the cancer patient population studied in the other cited series and our own [55].

In the attempt to bring some order to a heterogenous group of skull base tumors, Morita et al. recently classified cranial base tumors by the degree of aggressiveness into benign, intermediate malignant (or low grade/slow growing), and highly malignant (or fast growing) [56]. Applying this strategy to our series, 31 tumors in our series (84\%) would be classified as "highly malignant" or fast growing. Despite this unfavorable bias in our population, the tumor control rate in our series compared favorably to 


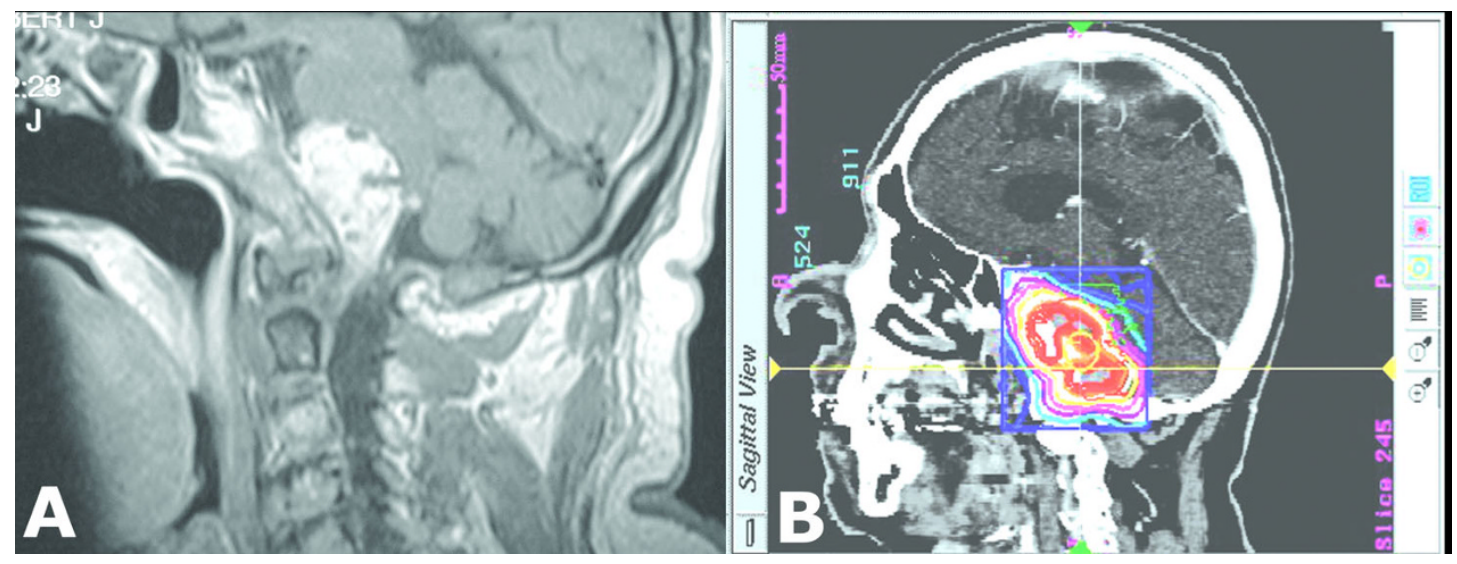

\section{Figure 5}

72 year-old man with a history of transitional cell carcinoma with a biopsy proven metastasis to the clivus and foramen magnum. He underwent prior radiation treatment with $60 \mathrm{~Gy}$ in 30 fractions. He presented to our institution with progressive facial numbness and difficulty swallowing. (A) Sagittal MRI of the brain after gadolinium administration demonstrating a large clival-based lesion compressing the pons and medulla. Having seen three other skull-base surgeons, none of whom offered surgical resection, we deemed the patient a good radiosurgery candidate. (B) Sagittal CT with treatment contour. The lesion was treated with 2000 cGy in 5 stages. He was followed for 4 I weeks when he died of failure to thrive. There was no radiographic progression of this lesion at the time of his last follow-up appointment.

the rate reported in the literature $[3,31,33,54,57]$. We treated 31 malignant skull base tumors with a median marginal dose of 2500 cGy delivered in 2-7 sessions (median of 5) and achieved a local control rate of $74 \%$ during the follow-up period (median 37 weeks). The median progression-free survival was 230 weeks. In separate analysis of the patients with tumors classified as "highly malignant", the local control rate in this subgroup of patients did not differ significantly from the total study population $(74 \%$ at 40 weeks), confirming the reported finding on metastatic tumors that response to radiosurgery may be independent of tumor characteristics [15]. Similarly, a comparison of patients who received radiosurgery as primary treatment versus adjunct treatment after surgery or radiotherapy did not reveal major differences in outcome.

Table 6: Summary of neurological deficits before and after CyberKnife radiosurgery

\begin{tabular}{lcccc}
\hline & \multicolumn{4}{c}{ No. of Patients } \\
\cline { 2 - 5 } Deficit & & \multicolumn{3}{c}{ Post-CKS } \\
\cline { 2 - 5 } & Pre-CKS & Improved & Stable & Worse \\
\cline { 2 - 5 } & 10 & 4 & 6 & 0 \\
Reduced visual acuity & 13 & 3 & 10 & 0 \\
Diplopia & 1 & 0 & 1 & 0 \\
Proptosis & 10 & 1 & 8 & 1 \\
Facial weakness & 7 & 0 & 6 & 1 \\
Facial pain & 4 & 0 & 3 & 1 \\
Swalowing difficulty & 3 & 0 & 3 & 0 \\
Hearing loss & & &
\end{tabular}

\section{Limitation of Toxicity}

Neurological deterioration occurred only in a minority of our patients and in each case, it was accompanied by local tumor progression. Neurological symptoms remained stable or improved in $94 \%$ of the patients. No neurological deficits were attributable to toxicity of radiosurgery. Although it is possible that a higher complication rate will emerge with longer follow-up, we believe that the lack of morbidity is largely the result of delivering radiosurgery in multiple sessions, with high conformality and homogeneity. Fractionation is a cornerstone principle in radiation oncology. The oncologist uses it to exploit the significantly different response to radiation of normal versus neoplastic tissue, for the protection of the former and ablation of the latter. It provides time for normal tissue repair between doses, and theoretically minimizes radiation toxicity. With the advent of frameless, image-guided radiosurgery, "hypofractionation" or multi-session treatment became possible. Adler et al. reported on their experience on multi-session radiosurgery for treating skull base, benign tumors situated within $2 \mathrm{~mm}$ of the optic apparatus. They achieved a high tumor control rate and found that $94 \%$ of the patients had stable or improved vision after treatment [46]. The authors believed that staging the treatment significantly contributed to the low incidence of radiosurgical toxicity. In addition to protective effects, the staging of radiosurgical treatments may have heretofore under-recognized tumor control benefits as well. A new report from Canada showed that patients who received staged radiosurgery to their brain metastases survived longer that those who received single-session treatment [58]. It is possible, that by allowing for a higher total 
dose delivery to the tumor, staging may lead to better tumor

control.

A recent report out of our institution demonstrated that the CyberKnife ${ }^{\circledast}$ radiosurgical system is capable of delivering a high dose of radiation to a well-defined clinical target volume with high conformity (median NCI 1.66) and homogeneity (median HI 1.26), regardless of irregular tumor shape, large tumor volume, or proximity to critical structures [59]. The median NCI in the present series was 1.60, and the median HI was 1.32. Although still controversial, it is our opinion that improved conformity and homogeneity may maintain high rates of local control while decreasing radiation-induced complications $[53,59-$ 61]. It seems intuitively evident that conformality and homogeneity are important in treating malignancies of the skull base, since all the tumors are in close proximity to, or entirely surround critical neurological structures that have limited radiation tolerance. In many instances, the encircled cranial nerve is not visible on the treatmentplanning image, and one must assume that it received the maximum dose.

\section{Dose and Staging Selection}

A significant majority of the patients in the present study received a does of $2500 \mathrm{cGy}$ in 5 stages. The initial selection of the dose and staging regimen stemmed from our group's experience using the CyberKnife ${ }^{\varpi}$ radiosurgical system to treat benign skull base lesions. Having encountered no neurological morbidity attributable to radiosurgery in this study, it is impossible to tell whether current treatment regimen represent the "ideal" dose to malignant skull base tumors. A higher average dose may lead to a better tumor control rate than the $74 \%$ seen in the present series, and still achieve an acceptably low rate of complications. It is also possible that the "ideal" dosing and staging is different for each patient, dependent on histopathology, previous treatments, tumor volume, neurological status and systemic tumor burden. Our confidence in raising the treatment dose, like the "true" complication rate, will no doubt come with time and further experience with these difficult tumors.

\section{Conclusion}

Despite the significant challenges, stereotactic radiosurgery appears to be a safe and reasonably effective treatment modality for the treatment of malignant primary, recurrent, and metastatic skull base tumors. Our experience suggests that image-guided, multi-session radiosurgery compares favorably to other radiosurgical techniques in the treatment of these difficult tumors. In addition, no major morbidity was observed as a direct result of this method. Longer follow-up and, optimally, comparison of dosimetry and other treatment parameters across institutions, will be necessary to more accurately define the long- term survival and effect of multi-session radiosurgery on disease progression for patients with these aggressive tumors.

\section{Competing interests}

The authors declare that they have no competing interests.

\section{Authors' contributions}

NC performed the chart review, organized data, analyzed data, drafted manuscript, created tables, obtained images. $D R$ assisted in the chart review, organization of data, and drafting of manuscript. YZ performed the statistical analysis and created statistical figures. $\mathrm{BC}$ participated in the treatment planning of patients included in this study. $\mathrm{KH}$ participated in the treatment planning of patients included in this study. GG participated in the treatment planning of patients included in this study. SC assisted in the organization of data, data analysis, table construction, literature review, and participated in the treatment planning of patients included in this study. WJ conceived of the study, participated in its design and coordination. Assisted in data analysis and drafting of manuscript.

\section{References}

I. Prabhu SS, Demonte F: Treatment of skull base tumors. Curr Opin Oncology 2003, I 5:209-2I2.

2. Sen C, Triana A, Hiltzik D, Costantino P, Lawson W, Urken M, Catalano P: Malignant tumors involving the lateral skull base. Clin Neurosurg 200I, 48:373-386.

3. Laigle-Donadey F, Taillibert S, Martin-Duverneuil N, Hildebrand J, Delattre JY: Skull-base metastases. J Neurooncol 2005, 75:63-69.

4. McGrew BM, Jackson CG, Redtfeldt RA: Lateral skull base malignancies. Neurosurg Focus 2002, I 2:e8.

5. Stark AM, Eichmann T, Maximilian Mehdorn H: Skull metastases: clinical features, differential diagnosis, and review of the literature. Surg Neurol 2003, 60:219-226.

6. Cantu G, Solero CL, Mariani L, Mattavelli F, Pizzi N, Licitra L: A new classification for malignant tumors involving the anterior skull base. Arch Otolaryngol Head Neck Surg 1999, I 25: I 252-I 257.

7. Ojemann RG: Skull-base surgery: a perspective. J Neurosurg 1992, 76:569-570.

8. Lewis JS: Temporal bone resection. Review of $\mathbf{1 0 0}$ cases. Arch Otolaryngol 1975, I0 I:23-25.

9. Smith RR, Klopp CT, Williams JM: Surgical treatment of cancer of the frontal sinus and adjacent areas. Cancer 1954, 7:991-994.

10. Alvarez I, Suarez C, Rodrigo JP, Nunez F, Caminero MJ: Prognostic factors in paranasal sinus cancer. Am J Otolaryngol 1995, I6:109-114.

II. Barrs DM: Temporal bone carcinoma. Otolaryngol Clin North Am 200I, 34:II97-1218. $x$.

12. Lunsford LD, Niranjan A, Martin JJ, Sirin S, Kassam A, Kondzoilka D, Flickinger JC: Radiosurgery for miscellaneous skull base tumors. Prog Neurol Surg 2007, 20:192-205.

13. Manolidis S, Pappas D, Von Doersten P, Jackson CG, Glasscock ME: Temporal bone and lateral skull base malignancy: experience and results with 81 patients. Am J Otol 1998, I9:SI-SI5.

14. DeMonte F: Surgery of skull base tumors. Curr Opin Oncol 1995, 7:201-206.

I5. Origitano TC, Petruzzelli GJ, Vandevender D, Emami B: Management of malignant tumors of the anterior and anterolateral skull base. Neurosurg Focus 2002, I 2:e7.

16. Anniko M, Franzen L, Lofroth PO: Long-term survival of patients with paranasal sinus carcinoma. ORL J Otorhinolaryngol relat spec 1990, 52:187-193.

17. Baier G, Volter C, Steigerwald I, Muller J, Schwager K: [Malignant paranasal sinus tumors diagnosis, therapy and results]. Hno 2005. 
18. Bentz BG, Bilsky MH, Shah JP, Kraus D: Anterior skull base surgery for malignant tumors: a multivariate analysis of $\mathbf{2 7}$ years of experience. Head Neck 2003, 25:5I5-520.

19. Jackson IT, Bailey MH, Marsh WR, Juhasz P: Results and prognosis following surgery for malignant tumors of the skull base. Head Neck 1991, 1 3:89-96.

20. Janecka IP, Sen C, Sekhar LN, Ramasastry S, Curtin HD, Barnes EL, D'Amico F: Cranial base surgery: results in 183 patients. Otolaryngol Head Neck Surg 1994, I I 0:539-546.

21. Francel PC, Bhattacharjee S, Tompkins P: Skull base approaches and gamma knife radiosurgery for multimodality treatment of skull base tumors. I Neurosurg 2002, 97:674-676.

22. Ganly I, Patel SG, Singh B, Kraus DH, Bringer PG, Cantu G, Cheesman A, De Sa G, Donald P, Fliss DM, Gullane P, Janecka I, Kamata SE, Kowalski LP, Levine PA, Medina Dos Santos LR, Pradhan S, Schramm V, Snyderman C, Wei WI, Shah JP: Craniofacial resection for malignant paranasal sinus tumors: report of an International Collaborative Study. Head Neck 2005, 27:575-584.

23. Kaplan ID, Adler JR, Hicks WL, Fee WE, Goffinet DR: Radiosurgey for palliation of base of skull recurrences from head and neck cancers. Cancer 1992, 70:1980-1984.

24. Lee N, Millender LE, Larson DA, Wara WM, McDermott MW, Kaplan MJ, Sneed PK: Gamma knife radiosurgery for recurrent salivary gland malignancies involving the base of the skull. Head Neck 2003, 25:210-216.

25. Nishioka T, Shirato H, Kagei K, Abe S, Hashimoto S, Ohmori K, Yamazaki A, Fukuda S, Miyasaka K: Skull-base invasion of nasopharyngeal carcinoma: magnetic resonance imaging findings and therapeutic implications. Int J Radiat Oncol Biol Phys 2000, 47:395-400.

26. Pollock $B E$, Foote $\mathrm{RL}$ : The evolving role of stereotactic radiosurgery for patients with skull base tumors. J Neurooncol 2004, 69: 199-207.

27. Alexander E, Moriarty TM, Davis RB, Wen PY, Fine HA, Black PM, Kooy HM, Loeffler JS: Stereotactic radiosurgery for the definitive, noninvasive treatment of brain metastases. J Natl Cancer Inst 1995, 87:34-40.

28. Terahara A, Niermierko A, Goietein M, Finkelstein D, Hug E, Liebsch N, O'Farrell D, Lyons S, Munzenrider J: Analysis of the relationship between tumor dose inhomogeneity and local control in patients with skull base chordoma. Int J Radiat Oncol Biol Phys 1999, 45:35।-358.

29. Cho $\mathrm{YH}, \mathrm{Kim} \mathrm{JH}$, Khang SK, Lee J-K, Kim CJ: Chordomas and chondrosarcomas of the skull base: comparative analysis of clinical results in $\mathbf{3 0}$ patients. Neurosurg Rev 2008, 3 I:35-43.

30. Hasegawa T, Ishii D, Kida Y, Yoshimoto M, Koike J, lizuka H: Gamma knife surgery for skull base chordomas and chondrosarcomas. J Neurosurg 2007, 1 07:752-757.

31. Iwai Y, Yamanaka K: Gamma Knife radiosurgery for skull base metastasis and invasion. Stereotact Funct Neurosurg 1999 72(SuppI I):8I-87.

32. Martin Jj, Niranjan A, Kondziolka D, Flickinger JC, Lozanne KA, Lunsford LD: Radiosurgery for chordomas and chondrosarcomas of the skull base. J Neurosurg 2007, I 07:758-764.

33. Tanaka T, Kobayashi T, Kobayashi T, Kida Y, Oyama H, Niwa M: The results of gamma knife radiosurgery for malignant skull base tumors. No Shinkei Geka 1996, 24:235-239.

34. Witt TC, Lo SS, Timmerman RD: Successful treatment of a skull base malignant rhabdoid tumor with surgery, chemotherapy and gamma Knife-based stereotactic radiosurgery in a young child. Stereotact Funct Neurosurg 2007, 85:310-313.

35. Aichholzer M, Bertalanffy A, Dietrich W, Roessler K, Pfisterer W, Unersboek K, Heimberger K, Kitz K: Gamma knife radiosurgery of skull base meningiomas. Acta Neurochir (Wien) 2000, 1 42:647-652.

36. Friedman WA, Foote KD: Linear accelerator-based radiosurgery for vestibular schwannomas. Neurosurg Focus 2003, 14(5):e2.

37. Kobayashi T, Kida Y, Hasegawa T: Long-term results of Gamma knife surgery for craniopharyngioma. Neurosurg Focus 2003, 14(5):

38. Kobayashi T, Kida Y, Mori Y: Gamma knife radiosurgery in the treatment of Cushing disease: long-term results. J Neurosurg 2002, 97:422-428.
39. Kondziolka D, Niranjan A, Lunsford LD, Flickinger JC: Stereotactic radiosurgery for meningiomas. Neurosurg Clin N Am 1999 , I 0(2):317-25.

40. Morita A, Coffey RJ, Foote RL, Schiff D, Gorman D: Risk of injury to cranial nerves after gamma knife radiosurgery for skull base meningiomas: experience in 88 patients. J Neurosurg 1999, 90(I):42-49.

4I. Pendl G, Eustachio S, Unger F: Radiosurgery as alternative treatment for skull base meningiomas. J Clin Neurosci 200 I, 8(Suppl I): I2-14

42. Petrovich Z, Yu C, Giannotta SL, Zee CS, Apuzzo ML: Gamma knife radiosurgery for pituitary adenoma: early results. Neurosurgery 2003, 53(I):5 I-59.

43. Thoren M, Hoybye C, Grenback E, Degerblad M, Rahn T, Hulting AL: The role of gamma knife radiosurgery in the management of pituitary adenomas. J Neurooncol 200I, 54(2): I 97-203.

44. Villavicencio AT, Black PM, Shrieve DC, Fallon MP, Alexander E, Loeffer JS: Linac radiosurgery for skull base meningiomas. Acta Neurochir (Wien) 200 I, I43( I I): I |4 I- I I52.

45. Witt TC: Stereotactic radiosurgery for pituitary tumors. Neurosurg Focus 2003, I4(5):

46. Adler JR, Gibbs IC, Puataweepong P, Chang SD: Visual field preservation after multisession CyberKnife radiosurgery for perioptic lesions. Neurosurgery 2006, 59:244-254.

47. Chang SD, Martin DP, Lee E, Adler JR: Stereotactic radiosurgery and hypofractionated stereotactic radiotherapy for residual or recurrent cranial base and cervical chordomas. Neurosurg Focus 200I, I0(3):

48. Elia AEH, Shih HA, Loeffler JS: Stereotactic radiation treatment for benign meningiomas. Neurosurg Focus 2007, 23(4): E5.

49. Wong ET, Lu XQ, Devulapalli J, Mahadevan A: Cyberknife radiosurgery for basal skull plasmacytoma. J Neuroimaging 2006, I6(4):36|-3.

50. Adler JR, Colombo F, Heilbrun MP, Winston K: Toward an expanded view of radiosurgery. Neurosurgery 2004, 55:1374-1376.

5I. Adler JR, Chang SD, Murphy MJ, Doty J, Geis P, Hancock SL: The Cyberknife: a frameless robotic system for radiosurgery. Stereotact Funct Neurosurg 1997, 69:124-128.

52. Nakamura JL, Verhey LJ, Smith V, Petti PL, Lamborn KR, Larson DA, Wara WM, McDermott MW, Sneed PK: Dose conformity of gamma knife radiosurgery and risk factors for complications. Int J Radiat Oncol Biol Phys 200 I, 5 I(5): |3 |3-1319.

53. Paddick I: A simple scoring ratio to index the conformity of radiosurgical treatment plans. Technical note. I Neurosurg 2000, 93(Suppl 3):219-222.

54. Cmelak AJ, Cox RS, Adler JR, Fee WE, Goffinet DR: Radiosurgery for skull base malignancies and nasopharyngeal carcinoma. Int J Radiat Oncol Biol Phys 1997, 37:997-1003.

55. Miller RC, Foote RL, Coffey RJ, Gorman DA, Earle JD, Schomberg PJ, Kline RW: The role of stereotactic radiosurgery in the treatment of malignant skull base tumors. Int J Radiat Oncol Biol Phys 1997, 39:977-98I.

56. Morita A, Sekhar LN, Wright DC: Current concepts in the management of tumors of the skull base. Cancer control 1998 , 5(2): $138-149$

57. Soltys SG, Adler JR, Lipani JD, Jackson PS, Choi CYH, Puataweepong $P$, White S, Gibbs IC, Chang SD: Stereotactic radiosurgery of the postoperative resection cavity for brain metastases. Int J Radiat Oncol Biol Phys 2008, 70(I): I87-193. Epub 2007 Sep 19.

58. Davey P, Schwartz ML, Scora D, Gardner S, O'Brien PF: Fractionated (split dose) radiosurgery in patients with recurrent brain metastases: implications for survival. Br J Neurosurg 2007, 2 I (5):49I-495.

59. Collins SP, Coppa ND, Zhang Y, Collins BT, McRae DA, Jean WC: CyberKnife radiosurgery in the treatment of complex skull base tumors: analysis of treatment planning parameters. Radiation Oncology 2006, I:46-55.

60. Maldaun MVC, Aguiar PHP, Lang F, Suki D, Wildrick D, Sawaya R: Radiosurgery in the treatment of brain metastases: critical review regarding complications. Neurosurg Rev 2008, 3 I : I-9.

61. Webb S: Conformal intensity-modulated radiotherapy (IMRT) delivered by robotic linac - testing IMRT to the limit? Phys Med Biol 1999, 44(7): I639-1654. 